\title{
Government work in Idi Amin's Uganda
}

\author{
Derek R. Peterson
}

On a sunny morning in May 2019 I visited Henry Kyemba at his modest house in Jinja, in eastern Uganda. ${ }^{1}$ Every wall is covered with photographs. Here is a photo of his brother, a member of the colonial-era Legislative Council. There, in an elegant frame, is Kyemba, proudly wearing cap and gown, on the day of his graduation from Makerere University. In a corner is a photo of President Milton Obote, cutting the ribbon at the opening of a hospital in Jinja. At the president's left hand is Kyemba, his secretary, holding the ribbon in place. In the middle of a wall is a photo of Idi Amin, smiling broadly as he clasps the hand of Kyemba's mother. Amin had visited the house a few weeks after he came to power in 1971. These and other photos cover the walls in the dining room, the kitchen, the study and the bedrooms. They are a record of Henry Kyemba's constant presence in the public life of postcolonial Uganda.

We sat on the veranda as Kyemba described how he had come to serve Idi Amin's government. He had accompanied President Milton Obote on a fateful trip to Singapore in January 1971. As the delegation was on its way back to Uganda, Kyemba - listening to the radio in the plane's cockpit - heard a notice saying that Idi Amin, commander of the Uganda Army, had overthrown Obote's government. Obote burst into tears when Kyemba told him the news. ${ }^{2}$ Their flight landed at Nairobi that night, and the following day Kyemba accompanied Obote as he went into an unhappy exile in Dar es Salaam. A few days after the coup, Kyemba - eager to be reunited with his family - telephoned Kampala and spoke with the new president, Idi Amin. Amin assured him that he had nothing to fear. On the day Kyemba landed at the airport in Kampala, President Amin sent a driver to meet him, and Kyemba drove with him to Amin's office. As they parted late that evening, Amin told him, 'I will see you on Monday.' Kyemba, mystified, asked, 'Where?' 'You are my secretary,' was Amin's reply. That is how Henry Kyemba - formerly the private secretary of Milton Obote - became the head civil servant in the government of Idi Amin (Kyemba 1977: 37-8).

Kyemba is proud of his record in public life. He sees himself as a professional, distant from the passions and posturing of politics. 'Promises, if they are to mean anything, have to be catered for,' he told me.

Here was a president who was offering heaven and earth at every [occasion]. They needed to be budgeted and planned for. It is not these barnstorming helicopter tours. You say,

\footnotetext{
Derek R. Peterson is Professor of History and African Studies at the University of Michigan and co-author of The Unseen Archive of Idi Amin: photographs from the Uganda Broadcasting Corporation (Prestel, 2021). Email: drpeters@umich.edu

${ }^{1}$ Interview with Henry Kyemba, Bugembe, Jinja, 26 May 2019.

${ }^{2}$ British National Archives (BNA), Foreign and Commonwealth Office (FCO) 31/1017: File note, 'A Second Republic', 20 February 1971.

(C) The Author(s), 2021. Published by Cambridge University Press. This is an Open Access article, distributed under the terms of the Creative Commons Attribution licence (http://creativecommons. org/licenses/by/4.0/), which permits unrestricted re-use, distribution, and reproduction in any medium, provided the original work is properly cited.
} 
'Oh, you need a bridge there.' Of course you do! But we need a thousand bridges ... If you want something done, assess it and plan for it. Who has got the priority? ${ }^{3}$

Despite personal tragedy - his brother was murdered by Amin's soldiers in 1972 Kyemba stayed in the job until 1977. There were many people - both in and outside government - who, like Henry Kyemba, saw themselves as public servants. At a time when the basic instruments of administration were in short supply, and when civilian authority was increasingly compromised by the whims of men with guns, a great many well-meaning people sacrificed themselves to make institutions work.

The first scholarly assessments of Idi Amin's regime were composed by historians and political scientists seeking to identify faults in the historical composition of Uganda. 'What went wrong with our independence?,' asked Semakula Kiwanuka. 'How can we prevent a recurrence of such tragedies?' (Kiwanuka 1979: 197). Like many others who sought to comprehend the 'Tragedy of Uganda', Kiwanuka wrote about a political inheritance that he hoped to transform. The first scholarly accounts had a forensic purpose: Samwiri Karugire, for example, titled his book the Roots of Instability in Uganda (2003 [1988]); while Mahmood Mamdani vowed to 'dissect every nerve and muscle of fascism' in order to 'identify the conditions and forces' that upheld Amin's regime (Mamdani 1984: 2). These scholars were supported by institutions that were rebuilding the country after years of devastating conflict. Mamdani's research, for example, was sponsored by the World Council of Churches; Will Kaberuka, author of a 1990 study, was economic adviser to Uganda's president (Kaberuka 1990). They differed in their political commitments, but the first scholars shared an underlying conviction that the 'social origins of violence' could be found in Uganda's history (Kasozi 1994). Abdu Kasozi, for instance, set out to 'locate the structural weaknesses in Uganda's society on which dictators and men of violence thrive' (ibid.: 5). His book ended with a conclusion listing the means by which Uganda's political malignancies could be ameliorated.

Today - fifty years since the coup - there is a new wave of historical writing about Idi Amin's Uganda. These new scholars are not encumbered by the pressing need to identify and root out the ills that afflicted Uganda's politics. Their focus, instead, is on the enduring professionalism of experts, government officials and others working in the public trust. Doreen Kembabazi, for example, draws from the archives of the Family Planning Association of Uganda to cast light on the medical doctors and philanthropists who expanded women's access to healthcare (Kembabazi 2020). Kate Bruce-Lockhart shows that prison warders - shaped by an inherited code of conduct - upheld standards and protected prisoners' dignity, even in times of awful violence (Bruce-Lockhart forthcoming). Marissa Mika draws on the remarkable archives of the Uganda Cancer Institute to show how medics struggled - in times of crippling financial constraint - to provide sick and suffering people with first-class care (Mika 2021). Taken together, these important new works show that Idi Amin's regime was, in many places, a state that worked (cf. Bierschenk and Olivier de Sardan 2014).

\footnotetext{
${ }^{3}$ Interview with Henry Kyemba, Bugembe, Jinja, 26 May 2019.
} 
I share with these scholars an admiration for the professionals - like Henry Kyemba - who, at a time of great danger, worked for the common good. At the same time, I think it important to acknowledge that professionals' authority was dramatically diminished. From 1973 onwards, price inflation crippled the Ugandan economy. The infrastructures that enabled and facilitated civic life were radically constrained. Everywhere there were shortfalls that compromised government bureaucracy: shortages of paper made it difficult to collect taxes or keep records; shortages of petroleum made it impossible to inspect schools or conduct land surveys; shortages of cement and corrugated iron made it hard to construct new buildings. These material and infrastructural austerities made it difficult for professionals to exercise supervisory, administrative power.

The diminution of bureaucrats' capacity opened up spaces where people outside government could shape public life. That was the consequence of the austerities of the 1970s: a rapid de-professionalization of civil administration. This article brings into view a category of political actors who I shall call commoners: people who were not invested with the titles, credentials or expertise that professionals possessed. Under Amin's government, a wide array of self-nominated, self-important, self-righteous people were empowered to take on administrative tasks that, in an earlier dispensation, had been the work of professionals. Businesses and institutions that had formerly been under the regulatory authority of credentialled experts were thrown open all at once for commoners to operate. Everywhere there were campaigns, as the new regime made obscure and technical issues into thrillingly consequential problems demanding a resolution. Ugandans were called upon to defend cultures, struggle against imperialism and racism, and transform the architecture of the economy. Commoners found themselves indiscriminately dragooned into service, as the urgent demands of public life drew an unlikely assortment of unqualified people to lay down their lives (Peterson and Taylor 2013).

That is how people came to see themselves as proprietors of public institutions. Their work allowed commoners to claim equity over resources and infrastructures. In their investments in the operations of public institutions, people became custodians, proprietors and petty authoritarians. Their proprietary sense of responsibility was a powerful inducement to self-sacrifice. It was also the fuel for demagoguery.

\section{Economies}

The cost of imported and manufactured goods rose dramatically in Ugandan marketplaces in the latter months of 1973. It was difficult to keep pace with the rate of price inflation. In October that year a cup of tea purchased in Kampala - priced at 3 shillings 50 cents in 1972 - cost 10 shillings. Primus stoves that had cost 45 shillings in 1972 had doubled in price; suits of clothes that had formerly cost 700 shillings were priced at $1,300.4$

\footnotetext{
${ }^{4}$ Kabarole District Archives (DA), 629/1: District Commissioner (DC) West Buganda to Permanent Secretary (PS), Ministry of Provincial Administration, 12 October 1973.
} 
The rapid rate of inflation made wage employment unprofitable. According to government statistics, the cost of living for low-income workers increased by 531 per cent between 1971 and 1977, while the cost of living for high-income groups rose by 234 per cent (Jørgensen 1981: 298; Kaberuka 1990: 261-3). Wages did not keep pace: the legal minimum wage was increased by a bare 40 per cent. Wage-earning employees had little reason to pursue their jobs. ${ }^{5}$ As prices rose, even a generous cash salary could be rendered valueless within a matter of months. The driver of Lira District's road grader was employed in July 1977 at a salary of 505 shillings a month. By January 1978 - six months after he signed his contract - he was demanding a raise of 400 shillings, saying that his salary would not allow him to make ends meet. ${ }^{6}$ A great many people removed themselves from formal employment. The sugarcane crop in eastern Uganda was unharvested in 1978, as no one could be found to work for the official wage. ${ }^{7}$ The same year, the whole staff of the Game Department in western Uganda summarily vanished. ${ }^{8}$

Lacking labour, spare parts and raw materials, Uganda's manufacturing economy ground to a halt. Uganda's farms produced 110,000 tons of sugar in 1973; in 1978, farmers produced only 3,000 tons. ${ }^{9}$ In 1971, Uganda produced 1.4 million hoes; in 1978, it produced only 333,000 (Jørgensen 1981: 296). These shortfalls made it hard for Ugandans to carry out simple transactions. There was a countrywide shortage of jute bags. Maize buyers in Busoga, in eastern Uganda, found it hard to collect the crop from farmers, as there was no means to convey it. ${ }^{10}$ Building contractors faced crippling shortfalls. In 1975, the contractor responsible for building several schools in Lango District was obliged to delay work for several months as he found it impossible to obtain boards for ceilings, door locks, nails or cement. ${ }^{11}$ Purchasing these goods on the black market, the contractor reported, would have bankrupted his company.

The Amin government responded to the inflationary pressure on prices by attempting to curate the economy. The State Trading Corporation was established by presidential decree in September 1972. It had a legal monopoly over the import and export of commodities. There were fixed prices for goods sold to consumers, and in every district there were government-appointed 'agents' who were responsible for the distribution and sale of commodities. These agents exercised monopoly powers. In Fort Portal, there were eight grocers who were authorized

\footnotetext{
${ }^{5}$ Library and Archives of Canada (LAC), RG 2512623 20-Uganda-1-4 pt. 7: Nairobi to Undersecretary of State for External Affairs, 12 September 1978.

${ }^{6}$ Lira District Archives (LDA), box 576, 'Population Census' file: Grader operator, Works Department, to Treasurer, East Lango District Administration, 3 January 1978.

${ }_{7}$ LAC, RG 2512623 20-Uganda-1-4 pt. 7: Nairobi High Commission to Undersecretary for External Affairs, 12 September 1978.

${ }^{8}$ Bundibugyo District Archives (BDA), box 539, 'Annual reports, other districts' file: Game Department, Fort Portal, to Acting Chief Game Warden, 29 May 1978.

${ }^{9}$ LAC, RG 2514495 20-Uganda pt. 4: CARE Uganda, 'Socio-economic Background of Uganda, 1970-1982'.

${ }^{10}$ Jinja District Archives (JDA), Comm. Dev. 9/25: Meeting to discuss the distribution of maize, 1 October 1976.

${ }^{11}$ LDA, box 523, file with no cover: John Sempa and Brothers to Works Supervisor, Lango, 14 January 1975.
} 
by government to sell commodities, at controlled prices. ${ }^{12}$ Bundibugyo's leading businessman, Haji Juma, was the government agent for Bata Shoes, the Voice of Uganda newspaper, fishing nets, and textiles. ${ }^{13} \mathrm{He}$ was also sheikh of the district's community of Muslims.

Retailers such as Haji Juma had little incentive to abide by the letter of the law. The government-mandated profit margin was vanishingly slim. Coffee was the crop where there were the greatest disparities between the official purchase price and the black market. A killing frost in Brazil destroyed two-thirds of the country's coffee bushes in 1975, undercutting the world's largest exporter of coffee. Ugandans hastened to take advantage. By an accident of geography, the most productive coffee-growing area in Uganda was in mountainous Bundibugyo, on the border with Zaire. The most prominent men of business in Bundibugyo were also the most successful smugglers. In 1970, officials reported that Haji Juma was purchasing low-grade coffee from Ugandan farmers, loading it into trucks and transporting it to the Zaire border. ${ }^{14}$ By the late 1970s, he and other smugglers were using government vehicles to spirit the coffee across the border. He and his cronies were 'receiving high class treatment from the Law Keepers here', reported a frustrated official. ${ }^{15}$ According to one estimate as much as US\$520 million in coffee was smuggled out of Uganda between 1975 and 1979 (Jørgensen 1981: 299; Bigsten and Kayizzi-Mugerwa 1999: 28-9; MacGaffey 1991).

Government officials preached that smuggling and illegal overcharging were moral faults, growing out of misplaced loyalties and self-serving greed. Early in 1975, President Amin appointed an 'Economic Crimes Tribunal'. The judges were military men, empowered to investigate and prosecute profiteers, hoarders and others who acted against the economic interests of the state. The penalty was death by firing squad, or ten years in prison. ${ }^{16}$ Well-connected smugglers were not brought before the Economic Crimes Tribunal; in fact, their profits allowed them to live in luxury. The Kenyan politician Michael Blundell visited Kampala in March 1978, at the height of the coffee boom. He thought the city 'appeared more orderly and prosperous' than it had in the early 1970s. ${ }^{17}$ Hotels were fully booked; there were well-stocked markets for food; and even the smaller shops had a plentiful supply of commodities. Blundell urged British firms to reinvest in Uganda, since the "country was on the brink of a period of stability and expansion'.

That is how people at the centre of the country lived, at the late flowering of Uganda's coffee-funded belle époque. Outside the capital, lifestyles were much more austere. Two days after Christmas 1976, an official in western Uganda arrested a man named Simeo Kahindo for selling goods without a

\footnotetext{
${ }^{12}$ Kabarole DA, 629/1: DC Toro to all county chiefs, 19 September 1973.

${ }^{13}$ BDA, box 509, 'Trade and Commerce' file: Trade Development Section, Bundibugyo, to PS, Ministry of Commerce and Industry, 4 August 1974.

${ }^{14}$ Kabarole DA, 628/1: Assistant DC Toro to DC Toro, 20 March 1970.

${ }^{15}$ Kabarole DA, 628/1: Thomas Arube, Cooperative Officer, Bwamba, to Assistant Administrator, 19 February 1978.

${ }^{16}$ 'Death for Hoarders and Price Pushers', Voice of Uganda 1 (656) (13 January 1975).

${ }^{17}$ BNA, FCO 31/2387: Blundell to Secretary of State for African Affairs, 2 April 1978.
} 
licence. ${ }^{18}$ The man had a wide supply of articles on hand. He had six coats, twelve shirts, two blankets and eight pairs of trousers for sale. He had one bed cover and four sheets. He had three pairs of shoes on offer. He had a radio, a bicycle and two belts. He had eight tablecloths, five neckties and two hoes. He had three kilograms of sugar and five kilograms of salt. And he had 64 shillings in cash. The official who arrested Kahindo totted all of this merchandise up in two numbered columns and dispatched the lot, together with Kahindo himself, to police headquarters in Fort Portal.

I do not know how Kahindo's business worked. Judging from the tiny amount of cash he had on hand it seems likely that much of his trade was conducted in barter. At a time when the value of cash was uncertain and changeable, Kahindo looked for profits through exchange, by assessing things comparatively, by knowing how the value of goods changed over space and time. It was men like him who actually responded to consumers' needs. Here was an arbiter who knew what people needed, who knew how to get hold of important things, and who found ways to convey them into consumers' hands.

\section{Austerity and government work}

How did local government function in a time of austerity? It took hard work. As supply chains withered, shops closed and the basic accoutrements of life grew hard to find, local government officers were increasingly encumbered with the obligation to make up shortfalls. Over the course of the 1970s, government became a do-it-yourself operation, as officials and citizens struggled to meet the responsibilities imposed upon them.

In 1974, President Amin restructured the administration of local government, introducing ten provinces and increasing the number of districts from nineteen to thirty-four. It was in these new districts that shortfalls in bureaucratic infrastructure were felt most urgently. A year after the founding of Bundibugyo District, the treasurer did not have stationery, revenue collecting forms or cash receipt books. ${ }^{19}$ The medical officer did not have rubber stamps to mark meat that had been found suitable for human consumption. The surveyor did not have a vehicle with which to traverse the district's mountainous territory. ${ }^{20}$ The organizers of the National Literacy Campaign did not have blackboards or chalk. ${ }^{21}$ No one had an office. Most departments of government subsisted in the community hall, which had been partitioned into tiny, airless cubicles. No one had paper. On several occasions the secretary could not distribute minutes for the monthly meetings of the district's executive committee, since paper was

\footnotetext{
${ }^{18}$ BDA, box 501, 'Uganda Police, 1974' file: Samuel Baker to Deputy Police Commander, Semuliki, 27 December 1976.

${ }^{19}$ BDA, box 507, 'Furniture' file: Treasurer, Semuliki District, to Provincial Executive Secretary, April 1975.

${ }^{20}$ BDA, box 513, 'Planning' file: District Team meeting, Semuliki, 26 July 1977.

${ }^{21}$ BDA, box 513, 'Planning' file: District Team meeting, Semuliki, 18 December 1974.
} 
not available. ${ }^{22}$ In one county, the chief had to suspend tax collection. ${ }^{23}$ There were no receipt books.

In Bundibugyo, as in many other places, the government bureaucracy only functioned when people sacrificed their time, energy and money. In the mid-1970s, government officials' uniforms throughout Uganda were made by men held in one of the central government prisons. They were tailored to a standard body size, and they seemed to fit no one properly. ${ }^{24}$ In one district policemen purchased a bale of American khaki, cut the cloth according to the measurements of each of the eighty-nine men, and stitched shirts and shorts. There were no boots, belts, caps, buttons or lanyards. ${ }^{25}$ Local officials in Bundibugyo had to wait for years to receive a copy of the Land Reform Decree of 1975.26 The district's land committee did not have a vehicle with which to inspect properties for which people had applied. It was applicants' responsibility to rent a vehicle that could transport the committee to the site of the property that he or she wished to obtain. ${ }^{27}$ It fell on applicants, too, to ensure that the paperwork moved smoothly through the government bureaucracy. When some applicants complained about the slowness of the land committee's work, committee officials told them to go to Fort Portal over a winding and broken road - to collect maps and the forms for processing. ${ }^{28}$

Even the highest-profile initiatives relied on the mandatory contributions of commoners. The costs of sending the Uganda delegation to the 1976 Olympics in Montreal were met through a countrywide fundraising campaign. ${ }^{29}$ Each parish was to contribute 50 shillings; each trading centre was to contribute 100 . The tourism industry likewise needed a subsidy from commoners. In 1976, the Minister for Tourism and Wildlife ordered local government authorities to conduct fundraising campaigns within their provinces, with the goal of generating money to print advertising brochures. ${ }^{30}$ In remote Bundibugyo, teachers hurriedly organized concerts featuring choirs of schoolchildren. Adults were charged a shilling each to attend; children paid 50 cents. ${ }^{31}$ In this way, schoolchildren and parents in one of Uganda's most remote localities found themselves - their money, their energy, their talent - dragooned into underwriting the running costs of a government ministry.

\footnotetext{
${ }^{22}$ BDA, box 513, 'Planning' file: District Team meetings, Semuliki, 22 April 1976 and 29 June 1976.

${ }^{23}$ BDA, box 531, 'Misc. 3' file: Subcounty Chief Harugale to County Chief Bwamba, 19 August 1974.

${ }^{24}$ BDA, box 502, 'Uniforms for Office Boys' file: PS, Ministry of Provincial Administrations, to all District Commissioners, 20 July 1977.

${ }^{25}$ Kabarole DA, 499/1: South Bunyoro District, police annual report for 1976.

${ }^{26} \mathrm{BDA}$, box 522, file with no cover: DC Semuliki to Provincial Commissioner for Land and Surveys, 21 September 1977.

${ }^{27}$ BDA, box 522, file with no cover: Semuliki District Land Committee, minutes, 28 November 1977.

${ }^{28}$ BDA, box 522, file with no cover: Semuliki District Land Committee, minutes, 29 November 1978

${ }^{29}$ LDA, box 592, 'Commonwealth Games Appeal' file: DC East Lango to all County Chiefs, 9 June 1976.

${ }^{30}$ Kabale DA, NW/CM box 11, 'Broadcasting, Information' file: Ministry of Tourism to all governors, 21 September 1976.

${ }^{31} \mathrm{BDA}$, box 523, 'National Parks and Tourism' file: District Education Officer to all Head Teachers, 11 October 1976.
} 
Infrastructure projects were similarly financed and built through commoners' energies and talents. The 'Self Help Projects Decree' made it obligatory for every county to prepare a yearly list of projects that could be pursued by communal labour. Once every month - or more often, if local authorities thought it right - residents were compelled to present themselves at county headquarters to work on collective projects. ${ }^{32}$ Self-help projects could be remarkably ambitious. In the south, local people completed work on fifty-five roads covering 371 miles over the space of one year. The standard was not particularly high. Volunteer work crews lacked tools. There were no lorries to carry crushed stone. ${ }^{33}$ There were no pipes for culverts, and drainage must have been a problem. Even so, local officials could rightly boast that local people had '[scored] spectacular achievements' through their communal labour. Local officials in Kasese - in the far west - built a stadium in the centre of town on the basis of self-help work. ${ }^{34}$ Each county was required to produce 6,000 blocks to use in the building. ${ }^{35}$ The stadium was completed in 1977.

The most ambitious initiatives were constrained by financial and material shortages. The stadium in Kasese began to collapse within months of its completion. The walls were built of impermanent materials, and when it rained, they sagged. ${ }^{36}$ Building projects in Bundibugyo were likewise built on shaky foundations. By November 1977 - three years after the founding of the district - there were no new structures to house local government offices. ${ }^{37}$ Workers had assembled heaps of stones at the county and subcounty headquarters, but the district's only tipper had been out of service for months. ${ }^{38}$ There was no cement, and neither was there sand with which to erect the walls. Road building, too, had largely ceased. Work had begun on a major trunk road in July 1978, but the driver of the road grader quit in October, as his rate of pay was too low to support him. ${ }^{39}$

Civil servants were obliged, often at considerable cost, to make up the difference between infrastructural needs and the shortfalls of government provision. There was an official scale setting out the donations required of subcounty and county chiefs on the occasion of a presidential visit to their localities. ${ }^{40}$ Local officials in Bundibugyo were obliged to finance the district's celebration of the fifth anniversary of Idi Amin's coup out of their own pockets. ${ }^{41}$ In one county, staff at the government headquarters were required to cultivate two-acre plots of cotton according to the official specifications. The district commissioner vowed that

\footnotetext{
${ }^{32}$ Kabarole DA, 1195/3: Self Help Projects Decree, 28 July 1975.

${ }^{33}$ Kabale DA, ADM 10, 'Department Annual Reports' file: Department of Community Development, annual report, 1973.

${ }^{34}$ Kasese DA, file with no cover: Minutes of Rwenzori District Team meeting, 19 April 1978.

${ }^{35}$ Kasese DA, file with no cover: Minutes of Rwenzori District Team meeting, 21 June 1978.

${ }^{36}$ Kasese DA, file with no cover: Minutes of Rwenzori District Team meeting, 6 September 1978.

${ }^{37}$ Kabarole DA, 303/1: Treasurer, Semuliki District, to Senior Road Inspector, 24 November 1977.

${ }^{38}$ Kabarole DA, 303/1: Treasurer, Semuliki District, to DC, 16 January 1978.

${ }^{39}$ BDA, box 521, 'Rural Development' file: Assistant Supervisor of Works to DC Semuliki, 22 March 1979.

${ }^{40}$ BNA, FCO 31/1018: John Byatt to G. Duggan, East Africa Department, 9 November 1971.

${ }^{41}$ BDA, box 513, 'Planning' file: District Team meeting, Semuliki, 19 January 1976.
} 
'our hectares will be an example for the village people and the visitors who will be coming to see cotton will first be shown our gardens'. ${ }^{42}$

The Amin government's expectations concerning local government authorities multiplied in proportion to the shrinkage of resources and the diminution of their salaries. As funding dried up, as machinery broke down, and as infrastructure crumbled, the obligations placed on civil servants grew. One of the Amin government's most demanding senior officers was Alex Owor, the governor of Western Province. In 1977 he circulated a letter to government authorities entitled 'Cleanliness and smartness of offices'. ${ }^{43} \mathrm{He}$ wanted staff to report at 7.30 a.m. sharp. He wanted toilets to be cleaned on a regular basis, since 'many of them have deteriorated, and in fact, there is a pungent stench emanating from there'. And he wanted office furniture to be upgraded. When a year later Owor toured Kasese District, he demanded that administrators should be 'clean shaven, they must trim their hair short and their finger nails, must not drink excessively, must not dress in torn clothes or shoes, not come to duty drunk'. ${ }^{44} \mathrm{He}$ made no provision of funds to enable government officers to purchase decent clothes; neither did he offer to furnish razors, shoes or furniture.

The Amin government transferred to individual government officials the obligation to make government look effective. It was hard for civil servants to keep track of their responsibilities. The most pressing imposition was on their time. In April 1978, President Amin paid a visit to Kigezi District. ${ }^{45}$ The visit was announced, over Radio Uganda, with only two days' advance notice. Officials scrambled to make preparations, and many people were caught unawares. One junior official abashedly explained that he was travelling to Kampala to collect a new suit of clothes on the day the visit was announced. The following day he had news that his wife, who lived near Kampala, had gone into labour prematurely. He had to travel home to attend to her welfare, and he therefore missed the president's visit. 46

The demands placed on local government officers were unrelenting. It was hard to carve out space for private life.

\section{The civil service}

In 2015, Doreen Kembabazi - then a doctoral student at the University of Michigan - coordinated a project to organize and catalogue the archives of the Central Police Station in Kampala (Kembabazi 2020). At the start it was impossible to get into the room where the archives were stored, for the shelves inside had collapsed, spilling their contents onto the floor and blocking the door. Once the

\footnotetext{
${ }^{42}$ Kasese DA, 'Bukonjo meetings' file: Bukonjo county meeting, 1 September 1976.

${ }^{43}$ Kabarole DA, 404/1 Acting Provincial Executive Secretary to all members, Western Province Team, 18 April 1977.

${ }^{44}$ Kasese DA, 'Circulars from DC Kasese' file: 'Report of the Honourable Governor, Mr Alex Owor's Tour of Rwenzori District', July 1978.

${ }^{45}$ Kabale DA, ADM 32, 'Presidential Visit to Kabale' file: 'Programme of HE the President's Visit to South Kigezi', n.d.

${ }^{46}$ Kabale DA, ADM 32, 'Presidential Visit to Kabale' file: John Musoke to District Commissioner South Kigezi, 12 April 1978.
} 
door was forced open, the archive revealed a wealth of interesting and incendiary things. We found a bag of counterfeit US dollars, left over from a police investigation. There was a spear, admitted as evidence in an assault case. One afternoon a student intern opened a box and found a bomb inside. In astonishment, the intern picked up the bomb. The police evacuated the building and the bomb squad removed it - gingerly - from the intern's hands. The cataloguing project was delayed for several weeks while the police swept the room for unexploded ordinance.

Like other public-facing institutions in Idi Amin's Uganda, the police force had to operate in conditions of material and technological constraint. At a time when most police forces were communicating by radio, Uganda's police were transmitting messages in Morse code. ${ }^{47}$ The holding cells at the Central Police Station were poorly built and insecure. The police were always short of petrol to fuel their vehicles. For these and for other reasons it was difficult to pursue investigations. A British police officer visited Uganda in July 1971, after Amin came to power. He found the police force in a 'state of disarray and unable to carry out its statutory duties' (Macoun 1996: 86). Several police officers had been killed by soldiers in retribution for their investigations into crimes committed by army officers. The British visitor thought the police force to be 'leaderless and demoralized'.

In contrast, security agencies that directly served the interests of Idi Amin's regime were provisioned luxuriously. The best-resourced agency of the Amin state was the State Research Bureau, which was responsible for pursuing internal enemies of the government. Its agents - who numbered 1,000 by 1977 - earned $\$ 350$ per day, got free lodging in state-run hotels, and drove in fast Toyotas fitted with radio equipment. British firms supplied the State Research Bureau with night-vision equipment, burglar alarms and anti-bomb blankets, while a US company sold the Bureau a telephone-tapping system (Mamdani 1984: 80-1). A journalist who saw the equipment shortly after Amin was driven out of power thought the telephone surveillance system to be the most sophisticated in Africa (Brock 1979). British diplomats regarded the State Research Bureau as a menace to good order.

The units are above the law and are made up of grotesque young men in dark glasses and funny hats, leather jackets and tight jeans. They snatch selected people from their homes in the early hours, and on the streets, beating up minor offenders before releasing them but, sometimes, battering the dangerous ones to a slow and horrible death. ${ }^{48}$

Financially and politically, the State Research Bureau was above the law. That is how the Amin regime worked: by starving institutions that protected the common good and by rewarding institutions that were instruments of Amin's will. It was a way of shrinking the political arena, of depriving citizens of access to resources to organize and pursue justice (Kasfir 1976). It was also a way of cultivating impunity.

Remarkably, though, the Central Police Station archive shows that, against the odds, the police of Idi Amin's time were conscientious about their work. They

\footnotetext{
${ }^{47}$ BNA, FCO 31/1369: 'The Uganda Police', March 1972.

${ }^{48}$ BNA, FCO 31/1586: High Commission Kampala, 'Learn to Love Big Dada', 28 February 1973.
} 
were investigating crimes, collecting evidence and protecting victims. There are over 4,000 case files from the 1970 s in the police archives. They show that the police were conducting investigations into burglaries, robberies, rapes and assaults. They pursued all of these investigations earnestly, even if their effectiveness was unclear. There is, for example, a file concerning a young man named Peter Kakooza, a cobbler. ${ }^{49}$ On 24 February 1974, Kakooza confronted a thief who had stolen a pair of shoes from him; the angry thief beat him with a stick. Kakooza came immediately to the police station to report the crime. On 4 March - two weeks after the incident - a police corporal made his way to Kakooza's stall to inquire about the incident. The cobbler could not be found. Neither could he be found on 21 May, when the policeman again sought him out. The file was closed the following day. I do not know why Kakooza did not pursue his complaint against his assailant. The case file demonstrates, though, that in this, as in many other instances, the police pursued the obligations of their office.

Diplomats were impressed by the professionalism of Uganda's civil service. In 1970, the year before Amin came to power, the government was the largest employer in the country: about 12 per cent of Ugandans in formal employment worked for the government. The civil service was ethnically balanced and, in the judgement of American diplomats, a 'reasonably competent body'.50 The head of the Institute of Public Administration, Michael Davies, thought Uganda's twenty district commissioners and 3,000 chiefs had a 'strong tradition of a degree of independence from the centre, and a reasonably equitable approach to the problems of their area, which they had tried hard to maintain' ${ }^{51}$ British diplomats agreed. 'Perhaps the most surprising aspect of the civil service is that it works as well as it does,' remarked one diplomat in December 1972.

The drainage system, electricity and water supplies work; the Bank of Uganda produces balance sheets; taxes are collected; the City Council keeps the city clean and carefully tends its numerous decorative flower beds; one can register and license one's car without having to resort to a bribe; men with pots inspect one's garden for mosquitoes. ${ }^{52}$

Bureaucrats knew how to tidy things up. Two weeks after Idi Amin came to power, he received a file full of minutes and policy recommendations from the secretary in the president's office. There was a great deal of paperwork: a note from the Minister of Education about the appointment of members of the senate at Makerere University; a recommendation about the future of the Miria Obote Charity Fund. In his covering letter, the secretary coached the new president through the file: 'I would suggest,' he wrote, 'that you ask the Minister of Education to brief you about these matters, after which you should consult

\footnotetext{
${ }^{49}$ Central Police Station archive (CPS), 'Daily Crime Bulletin, 1 January 1978-10 May 1978' file: Report for 9 May 1978. Seen courtesy of Doreen Kembabazi.

${ }^{50}$ United States National Archives (USNA), RG 59 SNF 1970-73, box 2645, file POL 15-2 1/1/ 70: Kampala to State Department, 18 May 1970.

${ }^{51}$ BNA, FCO 31/1234: M. Davies to Macoun, Overseas Police Advisor, n.d. (but August 1972).

${ }^{52}$ BNA, FCO 31/1234: John Stewart, British High Commission, to Wallace, East Africa Department, 1 December 1972.
} 
other Cabinet Ministers on these same matters. ${ }^{53} \mathrm{He}$ was trying to habituate President Amin to the routines of the bureaucracy. It was an invitation to consultative government.

Even the most reckless pronouncements of the president were subject to the regulatory work of government bureaucrats. In March 1972, an official from Kampala announced a 'research project on requests from district elders and His Excellency's promises'. ${ }^{54}$ Over the course of his first year in power, President Amin had barnstormed around the country, meeting with groups of citizens (Peterson and Vokes 2021). In many places the president had made unexpected promises: a hospital, a new road, a bridge. 'All of these requests and promises are now an important subject of research and analysis,' the official wrote. 'This means that we have to be as thorough and accurate as possible.' Local authorities were to make cost estimates for the projects that President Amin had promised to support. Government bureaucrats were working out plans that could - after the fact - turn the president's idiosyncratic and unpredictable promises into the basis of a coherent policy.

Civil servants were professionally invested in government institutions, but most often it fell to people outside government to make the bureaucracy work in the public interest. From a position outside government, commoners made serious and sustained efforts to bend the routines of administration to serve the common good.

In the archives of the Judiciary of Uganda - which have recently been organized by a team of students from the University of Michigan and Makerere University, working with Judiciary staff - there are dozens of files arising from litigation initiated by injured citizens intent on holding the authorities to account (Peterson 2021). In a time of great violence in public life, courageous people were opening up lawsuits against government officials who had wronged them. In October 1975, for example, Isibosesi Musebi - from Bugisu, in eastern Uganda - brought a civil suit against the Uganda government on behalf of his deceased brother. ${ }^{55}$ The brother had been arrested by a police corporal, then beaten and shot. Musebi sued for the costs of his brother's funeral and for the loss of income suffered by his family. A second file contains the plea of a man who was arrested and beaten by soldiers of the Uganda Army. He suffered permanent hearing loss in his right ear as a result. He asked for 20,000 shillings in damages. ${ }^{56}$ A third plaintiff was injured in her house in Nakawa, outside Kampala, by a stray bullet fired by a police officer. ${ }^{57} \mathrm{Her}$ arm was paralyzed.

These and other civil suits put the justices of the High Court in an impossible position. It was grievously dangerous to bring Amin's security men before the law. In one notorious case a prominent Kampala lawyer who represented a client abused by Amin's security men was arrested, beaten and tortured by agents of the regime (Kiwanuka 1979: 89-90). It is not surprising that the justices equivocated. Most of the civil suits brought by injured litigants against government officials did not receive a hearing. The case files were opened, the plaints were recorded,

\footnotetext{
${ }^{53}$ Uganda National Archives (UNA), Office of the President (OP) (new deposit), box 78, file CM/4/1: Personal Private Secretary to Amin, 12 March 1971.

${ }^{54}$ Kabale DA, Comm. box 20, 'National Research Council' file: Secretary for Research to DC Kigezi, 16 March 1972; JDA, ADM 3/14: Secretary for Research to DC Jinja, 16 March 1972.

${ }^{55}$ UNA, High Court archive, CL 006/010: Isibosesi Musebi v. Attorney General (AG), 1975.

${ }^{56}$ UNA, High Court archive, CL 033/067: Nansani Anonya v. AG, 1974.

${ }^{57}$ UNA, High Court archive, CL 015/035: Christine Nansamba v. AG, 1976.
} 
but the court heard no evidence and made no decisions. It was only in the early 1980s, after President Amin had been removed from power, that the court agreed to fix hearings for lawsuits initiated against Idi Amin's men.

Everyone involved in these lawsuits knew that they were on dangerous ground. Mr Musebi waited for a full year after his brother's unfortunate death before filing his suit. Did he wonder about the wisdom of taking Idi Amin's government to court? Did he hesitate, worried about the repercussions for himself and his brother's family?

The remarkable thing is that - even in the face of state-authorized violence, even at a time when civil institutions were decrepit and poorly resourced - so many people sought to make the legal bureaucracy work. The 'Daily Crime Logbook' in the police archives in Kampala shows that 1,029 crimes were reported during the five months between 1 January and 10 May 1978. In nearly 300 of these cases complainants physically apprehended suspects and presented them to the police to take into custody. One man, an employee of the East African Development Bank, brought in a suspect whom he accused of stealing twenty cans of paint from the bank's storeroom..$^{58}$ Another man brought in a suspect who had stolen a cloth from his shop. ${ }^{59}$ The manager of a hotel in Kampala brought in one of the waiters, whom he accused of stealing six drinking glasses. A manager at a construction site handed over one of his workmen for stealing six bags of cement. ${ }^{60}$ In several instances, indignant victims of crime seem to have apprehended dangerous criminals. In one case two men delivered two pickpockets to the police. Both of the men had been the targets of the pickpockets' attention. It seems likely that they worked together to identify and apprehend the people guilty of the crimes. ${ }^{61}$

People were taking matters into their own hands and pursuing the criminals who had wronged them. That is how people became - however unwittingly - vigilantes. Empowered by the dysfunction in the police force, emboldened by their outrage or by a sense of personal rectitude, Ugandans assumed the duties of the police force as their own. Whether out of passion, out of anger or out of grief, people deputized themselves for public service.

In Idi Amin's Uganda, government did not stand outside civil society, exercising oversight over the political order. In a time of infrastructural decrepitude and financial shortfall, the work of government relied on the participation and commitment of commoners. The relationship between governor and governed was levelled out, and all kinds of people - from busybodies and nosy parkers to self-righteous vigilantes - claimed an interest in the management of public life.

\section{Proprietorship}

Here was a do-it-yourself government. There was a widened basis for political authority as commoners, quite suddenly, felt themselves responsible for the

\footnotetext{
${ }^{58}$ CPS, 'Daily Crime Bulletin' file, 7 May 1978.

${ }^{59}$ CPS, 'Daily Crime Bulletin' file, 2 May 1978.

${ }^{60} \mathrm{CPS}$, 'Daily Crime Bulletin' file, 2 May 1978 and 30 April 1978.

${ }^{61}$ CPS, 'Daily Crime Bulletin’ file, 5 January 1978.
} 
management of public affairs. In this way, all of the phobias, passions and prejudices of popular culture became matters of official policy.

This was empowering for (some) commoners, who felt themselves newly invested with authority over matters about which they had no particular expertise. Even the most anonymous men felt enabled to take public affairs into their own hands. One man who appears repeatedly in the archives of the Amin presidency is Tito Bisereko. Bisereko - whose home was in western Uganda - signed himself in the simplest of terms, as 'A Local Farmer'. He began writing to Idi Amin in February 1976, when he sent the president a one-page typed missive entitled 'The world source of living peacefully'. ${ }^{62}$ In it he congratulated Amin for 'your wise decisions which have even shown Africa and the world at large that you are a dedicated leader of Africa'. In March 1976, Bisereko paid a visit to Kampala to discuss the borders of the country of Uganda with government officials, and afterwards he wrote up his notes on the meeting and sent them to President Amin. 'Marshall, from now onwards our National Map and Border Marks confirm each and every thing with our neighbouring countries, that Uganda shall ever stay with her 235,880 square kilometres only,' he wrote in a letter summarizing his findings. ${ }^{63}$ Bisereko had no expertise in the field of cartography. That did not stop him from commenting on the borders of Uganda, or on many other matters.

In November 1976, Tito Bisereko produced his most ambitious comment in government policy: a lengthy report describing his month-long walking tour from the Uganda-Zaire border in the west to Busia, on Uganda's eastern border with Kenya ${ }^{64}$ The report began with an assessment of the social problems that Bisereko had encountered. In the west he had seen Zairian smugglers flush with cash buying shirts and beer; in the east he had seen 'weak minded' Ugandans buying sugar and batteries at extortionate prices from Kenyan smugglers. He wanted smugglers detained in their villages. Bisereko thought that government should keep herders from pasturing their cattle along the verges of roads, since cattle 'trouble drivers and walkers on the road'. He warned that spinsters employed in government service 'do not fulfil their duties at all, they mostly stay on telephone just talking with their boyfriends'. These and other recommendations came in a list, organized paragraph by paragraph. There was advice on specific problems, too. Bisereko thought that the bar located near the hospital in Bundibugyo should be banned from playing dance music. He wanted government to regulate and inspect scales for meat in markets. He had advice on the location of schools in Mubende, on the provision of social services in Kampala, and about urban resettlement in Bukedi.

Tito Bisereko was unusual in the wideness of his travels, but his proprietary view of government work was widely shared. At a time when government institutions relied on the self-sacrificing donations of commoners, anonymous and unqualified people felt empowered to take an active part in matters of state.

It was a licence for demagoguery. One of the most demanding competitions that the Amin government conceived was the 'Keep Uganda Clean' campaign (Decker

\footnotetext{
${ }^{62}$ Kabarole DA, 402/1: Tito Bisereko to Idi Amin, 23 February 1976.

${ }^{63}$ Kabarole DA, 463/2: Tito Bisereko to President Amin, 19 March 1976.

${ }^{64}$ Kabarole DA, 102/2: Tito Bisereko to Idi Amin, 26 November 1976.
} 
2010). Launched in 1973, the campaign offloaded the work of urban sanitation onto Ugandan commoners. 'Government attaches great importance to cleanliness and tidiness in all aspects of life,' the District Commissioner in Bundibugyo told residents in a circular. ${ }^{65}$ Trading premises and private homes were to be kept 'absolutely clean and tidy'. For its advocates, the campaign was a moral responsibility, not simply an administrative matter. Those who did not join were made out to be malingerers. On 21 September 1973, the city council in Kampala took the lead in a day-long effort to clean up the city's streets. Newsmen reported that workers threw mud at idlers, saying, 'Why don't you join us? Do you fear to have soil on your hands?' Taxi drivers were dragooned into service. One of the leaders of the campaign shouted: 'We cannot work to clean our country while others are enjoying an evening drive. ${ }^{66} \mathrm{~A}$ self-righteousness pervaded campaign work. It made petty tyranny appear justified.

In this way a great many people came to be vested in state institutions. Having been called to serve in the campaigns that the Amin regime launched, people felt entitled to the exclusive ownership of business, institutions and other public entities. It was urgently necessary to identify and liberate institutions that were under the unjustifiable control of outsiders. Commoners' proprietorship over public institutions was a form of exclusion and control. It made outsiders with competing claims appear to be usurpers.

Late in 1971, President Amin convened a two-day conference in Kampala about the status of Uganda's Asians. In his opening speech, President Amin harangued the Asian community for its disloyalty. Asian businessmen habitually overcharged African customers for basic commodities, then smuggled the profits of their businesses out of the country into foreign accounts. Amin dramatized the insularity of the Asian community by reading out a letter from an anonymous Asian girl who had married an African. Asian people 'say that for an African to marry with an Indian is like a dog who sleeps on his master's bed and is chased away very quickly', the author wrote. These and many other instances, President Amin argued, showed that Uganda's Asians had 'no interest in this country beyond the aim of making as much profit as possible'. ${ }^{67}$

For many people, Amin's condemnations of Asian businessmen struck a chord, resonating with personal experience (Taylor 2015; see Brennan 2012). Shortly after Amin's speech an otherwise unremarkable man named Moses Adribi wrote to the president, thanking him for 'having mentioned frankly to Indians the very malpractices they inflict on Africans' ${ }^{68}$ Adribi had his own story of discrimination to tell. The director of Gardens and Curios Ltd in Kampala, an Indian, compelled Adribi and other employees at the curio shop to work long hours without overtime pay. It was an insult to Uganda's sovereignty. 'It fills our hearts with deep sorrow and profound annoyance,' Adribi wrote, 'to see that a mere individual who smuggles money out of our country and apparently

\footnotetext{
${ }^{65} \mathrm{BDA}$, box 512, 'Trade and Commerce' file: DC Semuliki, circular to all traders, 19 March 1974.

${ }^{66}$ 'Kampala excels in keep Uganda clean', Voice of Uganda 1 (251) (22 September 1973).

${ }^{67}$ USNA, RG 59 SNF 1970-73, box 2644, file POL 15-1 1/1/71: Ferguson to State Department, 23 December 1971.

${ }^{68}$ UNA, OP (new deposit), box 28, file C.10766 vol. III: Moses Adribi to President Amin, 12 December 1971.
} 
has no national interest keeps us working more than what he states before our government.'

In August 1972, President Amin summarily ordered the expulsion of Uganda's Asian community. Some 50,000 people - many of whom had lived in Uganda for generations - were given a scant three months to tie up their affairs and leave the country. Amin called it the 'Economic War'. In the speech that launched it, he argued that 'the Ugandan Africans have been enslaved economically since the time of the colonialists'. ${ }^{69}$ The Economic War was meant to 'emancipate the Uganda Africans of this republic'. Like the other campaigns that Amin's regime launched, it demanded self-sacrifice and civic participation.

This is the day of salvation for the Ugandan Africans. This is the day of the redemption of the Ugandan Africans. All Ugandans must wake up, in full and total mobilization, determined and committed to fight this economic war until it is won. This is the time for all of us to rise and fight this war of economic liberation.

By the end of 1972, 5,655 farms, ranches and estates had been vacated by the departing Asian community (Jørgensen 1981: 288). The abandoned properties fell under the custodianship of a new bureaucracy - the Departed Asians Property Custodial Board - whose role it was to allocate houses and business premises to African tenants. In Jinja town - long the home to a thriving Asian community - twenty-one business premises were allocated to employees of local government. Three shops were given to wives of senior civil servants. Nine premises were allocated to teachers, and five employees of the medical department were given shops. ${ }^{70}$ The management of the Kakiira sugar factory - previously owned by Asian businessmen - was handed over to African proprietors. Workers newly recruited to manage the requisitioned Asian business remember their bewilderment and perplexity at the complexity of the job. ${ }^{71}$ 'Men who had recently had nothing had become rich bosses overnight,' recounted historian Phares Mutiibwa. 'Former cooks in Asian households moved into their former masters' bedrooms ... Even professors and lecturers at Makerere abandoned their ivory towers and joined the great scramble for businesses' (Mutiibwa 1992: 115-16).

A great many projects, initiatives and institutions - previously short of space found a home in buildings vacated by Indian and Pakistani owners. Much of the funding for the 1975 meeting of the Organization of African Unity - held in Kampala - came from the Departed Asians Property Custodial Board. The offices of the Ministry of Information and Broadcasting in Jinja town were located in what had been the Gymkhana club. ${ }^{72}$ In Bundibugyo, shops formerly operated by Asian businessmen furnished local authorities with offices. The town council moved into one vacant shop; the growers' cooperative society moved into another; the forestry department moved into a third. ${ }^{73}$ In times of

\footnotetext{
${ }^{69}$ UNA, Mbale DA, box 23, file MBL 11/7: 'Message to the Nation on British Citizens of Asian Origin', 12-13 August 1972.

${ }^{70}$ JDA, box 117, TRD 1: Administration Department, list of shops allocated, 1973.

${ }^{71}$ Interview with Augustine Osuman, Soroti town, 31 January 2020.

${ }^{72}$ JDA, ADM Central 4/11: Eastern Province, minutes, 27 March 1974.

${ }^{73}$ BDA, box 503, 'Motor and Other Vehicles' file: District Administrator to PS, Office of the President, 5 June 1987.
} 
austerity, when concrete and mortar were in short supply, requisitioned Asian properties helped bridge the gap between the ambition of government programmes and the reality of shortages, deficits and breakdown.

Uganda's commoners found themselves engaged in a front-line struggle to build a new economic order. The smoothness and professionalism of commercial transactions were the proof of Africans' capacity for economic self-government. The 'days of bargaining are done', read a headline in the Voice of Uganda. The public expected the 'new shopkeeper in their town or village to be dedicated and very hard working', a 'man of integrity and honesty'. ${ }^{74}$ In March 1973, three months after the Asians were expelled from Uganda, the Trade Development Officer in a town in western Uganda convened a short course for the town's African retailers. He was full of advice and direction about the conduct of business. It was important that men of business should be 'courteous, alert, friendly, and ready to serve. To deserve goodwill you should be even tempered and calm.' Fixtures and equipment in the shop should be kept clean and tidy, and so should the shop counter, for 'the cumulative effect of dirt and smudges on display cases can [harm] the sale's effectiveness'. ${ }^{75}$ All of this required a monastic discipline. Success in business meant 'very hard work, saving every cent', said an official of the Ministry of Commerce and Industry at another training course. 'It means denial of oneself's pleasures and leisure.' 76 Here was a calling, a vocation, that principled and idealistic men could pursue. Here also were criteria that government officials could use to manage the economy. In the time following the expulsion, President Amin made surprise visits to businesses in Kampala two or three times every week. On every tour of inspection he would tell proprietors to change their method of work, report on their profits, or change the arrangement of stock. ${ }^{77}$

A great many properties were vacated in those days. A great many lives were uprooted. A great many people were expelled, cast out of Uganda. All of this was in the name of liberation. President Amin ordered the Israelis to leave Uganda in March 1972. They were given three weeks to pack up their possessions. In 1973, the government outlawed several Pentecostal Christian denominations. ${ }^{78}$ In 1977, twenty-seven religious organizations were banned, among them the Baha'is, the Baptists, the Holy Ghost Church of East Africa, the Dini ya Roho and the Nomiya Luo Church. ${ }^{79}$ Their buildings were given to government departments or establishment churches. Some people were killed in punishment for their refusal to bend the knee to Amin's authority.

That is how the private property of religious and cultural minorities came under the management of the black majority. Government work was being outsourced to uncredentialled commoners, and Ugandans were being invited to exercise

\footnotetext{
${ }^{74}$ 'Days of bargaining are gone', Voice of Uganda 1 (7) (9 December 1972).

${ }^{75}$ Kasese DA, 'Staff Meetings and Traders Meetings' file: Meeting for Kasese traders, 15 March 1973 .

${ }^{76}$ Kasese DA, 'Staff Meetings and Traders Meetings' file: Senior Assistant Secretary, Ministry of Commerce and Industry, 4 October 1973.

${ }^{77}$ BNA, FCO 31/1586: British High Commissioner to FCO, 23 January 1973.

${ }^{78}$ Kabarole DA, box 382, file 2: Minister of Internal Affairs, Penal (Unlawful Societies) Order, 31 May 1973.

${ }^{79}$ Kabarole DA, box 382, file 3: DC Toro to all county chiefs, 18 October 1977.
} 
proprietary power over civic institutions. By what right, then, could racial and religious minorities control parts of Uganda's cultural and political economy? The disentitlement of minorities went hand in hand with the popular effort to assert commoners' exclusive ownership over civil, economic and religious life.

\section{Conclusion}

Henry Kyemba - who had been Idi Amin's secretary, then Minister of Culture, and finally Minister of Health - fled Uganda into exile late in April 1977. From a flat in London he set to work composing an exposé that brought the terrible violence of Amin's government to light. The book was published in September 1977, just in time for the meeting of the United Nations General Assembly. Entitled State of Blood, Kyemba's book was translated into nineteen different languages. In the months following its publication, he talked about the book on 60 Minutes, The Today Show and Good Morning America and in a number of other venues.

I have argued here that the Amin regime was not, in fact, a state of blood. It was self-sacrifice that made the Amin regime work. The essential things that made the bureaucracy function were in short supply; the infrastructure of the economy was in disorder. These shortages and austerities deprived experts of their authority and bureaucrats of their procedural power. Commoners - their expertise, their knowledge, their funds - were called upon to subsidize the work of government. Some people came to see themselves as owners of public institutions. It was this feeling of empowerment that could animate works of great self-sacrifice. It was an impetus to cover up deficiencies, shortfalls and gaps, to become infrastructural prosthetics' for an overburdened civil service (Park 2017).

Their sacrificial investments in public institutions also made some people into self-righteous demagogues. In Uganda, as in other places in postcolonial Africa, economic crises have given rise to campaigns against minorities, outsiders and morally disentitled people. Self-righteous custodians have launched a great many crusades to liberate economies and cultures from the grasp of freeloaders. In Ghana, aggrieved businessmen launched the 'National Crusade for the Protection of Ghanaian Enterprises' in 1968. Crusaders aimed to mobilize 'indigenous' Ghanaians to seize control of the country's commercial sector. The 'Aliens Compliance Order', adopted by government in 1969, gave foreigners living in the country two weeks to obtain residence permits. In the days that followed, over 100,000 people were summarily expelled from Ghana (Peil 1971; Quarshie 2021). In Nigeria, the government of Shehu Shagari responded to financial crisis by expelling 3 million foreigners from the country in 1983. Government agents were ordered to inspect businesses and households to flush out 'defaulting aliens' (Aluko 1985). In South Africa, xenophobic attacks on immigrants from Zimbabwe and Botswana have been driven by black South Africans' efforts to guard their freedoms (Nyamnjoh 2006). In a place where rights and economic opportunities have only recently been won, patriotic people feel compelled to defend moral and political ground against the usurpations of foreigners.

Austerities in government services have led many people to subsidize public institutions with their sweat and their treasure. It is a responsibility, an edifying 
test of civic virtue. It is also a rationale for prejudice and a platform for chauvinism. It is the place from which the vocation of the patriot and the demagogue both come.

\section{References}

Aluko, O. (1985) 'The expulsion of illegal aliens from Nigeria: a study in Nigeria's decision-making', African Affairs 84 (337): 539-60.

Bierschenk, T. and J. Olivier de Sardan (eds) (2014) States at Work: dynamics of African bureaucracies. Leiden: Brill.

Bigsten, A. and S. Kayizzi-Mugerwa (1999) Crisis, Adjustment, and Growth in Uganda: a study of adaptation in an African economy. London: Macmillan.

Brennan, J. (2012) Taifa: making nation and race in urban Tanzania. Athens $\mathrm{OH}$ : Ohio University Press.

Brock, G. (1979) 'How Amin equipped his army', The Observer, 30 December.

Bruce-Lockhart, K. (forthcoming) Carceral Afterlives: the prison in postcolonial Uganda. Athens $\mathrm{OH}$ : Ohio University Press.

Decker, A. (2010) 'Idi Amin's dirty war: subversion, sabotage, and the battle to keep Uganda clean, 1971-1979', International Journal of African Historical Studies 43 (3): 489-513.

Jørgensen, J. (1981) Uganda: a modern history. New York NY: St Martin’s Press.

Kaberuka, W. (1990) The Political Economy of Uganda, 1890-1979: a case study of colonialism and underdevelopment. New York NY: Vantage Press.

Karugire, S. (2003 [1988]) Roots of Instability in Uganda. Kampala: Fountain Publishers.

Kasfir, N. (1976) The Shrinking Political Arena: participation and ethnicity in African politics. Berkeley CA: University of California Press.

Kasozi, A. B. K. (1994) The Social Origins of Violence in Uganda, 1964-1985. Montreal: McGill-Queen's University Press.

Kembabazi, D. (2020) 'The state of morality: sexual, reproductive and sartorial politics in Idi Amin's Uganda'. PhD thesis, University of Michigan.

Kiwanuka, S. (1979) Amin and the Tragedy of Uganda. Munich: Weltforum Verlag.

Kyemba, H. (1977) State of Blood. New York NY: Ace Books.

MacGaffey, J. (1991) The Real Economy of Zaire: the contribution of smuggling and other unofficial activities to the national wealth. Philadelphia PA: University of Pennsylvania Press.

Macoun, M. (1996) Wrong Place, Right Time: policing the end of empire. London: Radcliffe Press.

Mamdani, M. (1984) Imperialism and Fascism in Uganda. Trenton NJ: Africa World Press.

Mika, M. (2021) Africanizing Oncology: an historical ethnography of cancer research in Uganda. Athens $\mathrm{OH}$ : Ohio University Press.

Mutiibwa, P. (1992) Uganda since Independence: a story of unfulfilled hopes. London: Hurst and Co.

Nyamnjoh, F. (2006) Insiders and Outsiders: citizenship and xenophobia in contemporary South Africa. Dakar: CODESRIA Books. 
Park, E. (2017) 'Infrastructural attachments: technologies, mobility, and the tensions of home in colonial and postcolonial Kenya'. PhD thesis, University of Michigan.

Peil, M. (1971) 'The expulsion of West African aliens', Journal of Modern African Studies 9 (2): 205-29.

Peterson, D. R. (2021) 'The politics of archives in Uganda' in T. Spear (ed.), The Oxford Research Encyclopedia of African History. Oxford: Oxford University Press.

Peterson, D. R. and E. C. Taylor (2013) 'Rethinking the state in Idi Amin's Uganda: the politics of exhortation', Journal of Eastern African Studies 7 (1): 58-82.

Peterson, D. R. and R. Vokes (2021) The Unseen Archive of Idi Amin: photographs from the Uganda Broadcasting Corporation. Munich: Prestel.

Quarshie, N. (2021) 'Mass expulsion as internal exclusion: police raids and the imprisonment of West African immigrants in Ghana, 1969-1972' in M. Morelle, F. le Marcis and J. Hornberger (eds), Confinement, Punishment and Prisons in Africa. London: Routledge.

Taylor, E. C. (2015) 'Asians and Africans in Ugandan urban life, 1959-1972'. PhD thesis, University of Michigan.

\begin{abstract}
Under Idi Amin's government, institutions that served the public interest were dramatically under-resourced. An array of self-nominated, self-important, selfrighteous people were empowered to take on administrative tasks that, in an earlier dispensation, had been the work of professionals. Businesses and institutions that had formerly been under the regulatory authority of credentialled experts were thrown open all at once for commoners to operate. Everywhere there were campaigns, as the new regime made obscure and technical issues into urgent problems demanding a resolution. Ugandans were called upon to defend cultures, to struggle against imperialism and racism, and to transform the architecture of the economy. That is how people came to see themselves as proprietors of public life. Their work allowed commoners to claim equity over resources and infrastructures. In their investments in the operations of public institutions, people became custodians, proprietors and petty authoritarians. Their proprietary sense of responsibility was a powerful inducement to self-sacrifice. It was also the fuel for demagoguery.
\end{abstract}

\title{
Résumé
}

Sous le gouvernement d'Idi Amin, les institutions qui servaient l'intérêt public manquaient cruellement de ressources. Un tas de personnes infatuées et vaniteuses auto-désignées furent autorisées à assumer des tâches administratives qui, sous le régime précédent, étaient assurées par des professionnels. Les portes d'entreprises et d'institutions jusqu'alors placées sous l'autorité réglementaire d'experts accrédités furent tout d'un coup ouvertes à des gens ordinaires. Des campagnes s'organisèrent partout, le nouveau régime faisant de problèmes techniques et obscurs des problèmes urgents à résoudre. Les Ougandais furent appelés à défendre les cultures, à lutter contre l'impérialisme et le racisme, et à transformer l'architecture de l'économie. C'est ainsi que les citoyens en vinrent à se considérer 
eux-mêmes comme des propriétaires de la vie publique. Leur travail, en bref, autorisa les gens ordinaires à réclamer l'équité des ressources et des infrastructures. Dans leurs investissements dans l'exploitation des institutions publiques, les citoyens devinrent des gardiens, des propriétaires et des petits despotes. Leur sens propriétal de la responsabilité fut une incitation puissante à l'abnégation. Il alimenta aussi la démagogie. 